\title{
Konsep Pendidikan Akhlak Menurut Sa’id Hawwa
}

\author{
Tuti Awaliyah \\ Institut Agama Islam Darussalam (IAID) Ciamis \\ Email: tuti_awaliyah@yahoo.co.id \\ Nurzaman \\ Universitas Pendidikan Indonesia (UPI) Bandung \\ Email: nurzaman.upi@gmail. com
}

Received: December 16, 2017 | Accepted: March 17, 2018

\begin{abstract}
This study attempts to explain the concept of moral education according to Sa'id Hawwa. The results showed that (1) moral education according to Sa'id Hawwa is to form the child's personality in an Islamic way so that they have solid moral foundation and Islamic knowledge. The moral basis according to Sa'id Hawwa is loyalty only to Allah, the Messenger of Allah, and the believers; the love of a servant to God; being gentle towards the believers; being stern against the unbelievers; and jihad in the way of Allah.
\end{abstract}

\begin{abstract}
Abstrak
Penelitian bertujuan untuk mengelaborasi pemikiran Said Hawwa tentang pendidikan akhlak. Penelitian ini dipandang penting mengingat problem etika yang dihadapi masyarakat modern sangat serius. Dengan menggunakan metode analisis isi, penelitian ini menghasilkan sejumlah temuan, yaitu pendidikan akhlak menurut Sa'id Hawwa yaitu membentuk kepribadian anak secara Islami agar memiliki dasar akhlak yang kokoh serta ilmu pengetahuan yang Islami. Selain itu, dasar-dasar akhlak menurut Sa'id Hawwa adalah loyalitas hanya kepada Allah, Rasulullah, dan orang-orang mukmin; cinta seorang hamba kepada Allah; bersikap lemah lembut terhadap orang-orang mukmin; bersikap keras terhadap orang-orang kafir; serta berjihad di jalan Allah.
\end{abstract}

\section{Keywords}

Islamic education, moral education, value education 


\section{Pendahuluan}

Realitas krisis akhlak di Indonesia sekarang ini masih nampak begitu memprihatinkan. Ketidakjujuran muncul di mana-mana, perilaku kejahatan dan perlakuan tidak manusiawi hampir setiap hari diberitakan di media masa. Pemimpin yang amanah dan bisa dijadikan teladan masih sulit ditemukan. Praktik KKN (Korupsi, Kolusi dan Nepotisme) masih saja terjadi di berbagai lembaga, meskipun berbagai upaya pencegahan dan penegakan hukum terus diupayakan pemerintah. Ditinjau dari dampak negatif perkembangan iptek terhadap dunia anak dan remaja menimbulkan beberapa masalah sosial baru, seperti penculikan anak, individualis, pornografi, narkoba, dan pergaulan bebas sehingga nilai-nilai yang menjadi patokan perilaku mereka menjadi kabur.

Umat yang tengah bangkit sangat membutuhkan akhlak; akhlak yang utama, kokoh, dan kuat. Juga jiwa yang besar, obsesif dan ambisius. Sebab umat akan menghadapi berbagai tuntutan era baru, yang tidak dapat dipenuhi kecuali dengn akhlak yang kuat, tulus dan terpancar dari iman yang mendalam, ketegaran yang kokoh, pengorbanan yang besar, dan mental yag tahan uji. Dan yang mampu mencetak kepribadian sempurna ini, hanyalah Islam. Islamlah yang menjadikan keshalihan dan kesucian jiwa sebagai pondasi kesuksesan. Islam menegaskan bahwa perubahan urusan umat selaras dengan perubahan akhlak dan keshalihan jiwanya. Allah swt berfirman, "Sesungguhnya, Allah tidak mengubah keadaan suatu kaum sehingga mereka mengubah keadaan yang ada pada mereka sendiri. "(Q. S. Ar-Ra'du: 11). (Banna, 2012, p. 133)

Sa'id Hawwa menjelaskan termasuk di dalam pembentukan kepribadian manusia secara Islami adalah kewajiban setiap individu untuk membentuk kepribadian keluarganya, dan pada akhirnya mengajak umat manusia untuk membentuk kepribadian mereka masing-masing secara Islami (Hawwa, 2002, p. 33). Yang dimaksudkan Sa'id Hawwa dengan kewajiban membentuk kepribadian manusia secara Islami adalah hendaknya setiap individu memiliki etika-etika fundamental dan ilmu pengetahuan yang Islami. Kelima etika fundamental itu diantaranya adalah loyalitas hanya kepada Allah swt dan Rasululah saw, cinta kepada Allah swt; bersikap pengasih kepada kaum mukminin; bersikap tegas kepada golongan kafir; dan jihad. Karena yang menjadi titik tolak bagi kita kaum muslimin di dalam segala hal adalah upaya untuk menghidupkan kembali manusia dengan ilmu pengetahuan dan pendidikan (tarbiyah). Tanpa ilmu pengetahuan serta tarbiyah, maka membentuk kepribadian manusia secara Islami tidak akan berhasil.

Berdasarkan latar belakang pemikiran yang telah penulis uraikan di atas, maka penelitian ini di arahkan untuk mengkaji pemikiran Sa'id Hawwa yang difokuskan pada konsep pendidikan akhlak. Adapun faktor yang 
melatarbelakangi penulis memilih tokoh tersebut, adalah: Pertama, kompetensi mumpuni beliau dalam bidang pendidikan akhlak, dakwah, dan pergerakan. Hal tersebut terbukti dengan karya tulisnya dan juga pendapat para sahabat dan beberapa tokoh yang mengenalnya. Khusus dalam bidang akhlak, beliau menawarkan pemikiran akhlak Islam utama dan integral yang diyakini mampu membangun totalitas manusia, manifestasi kesempurnaan sdan ketinggian ubudiyah kepada Allah. Kedua, kepribadian beliau yang zuhud, keikhlasan dan keistiqamahannya dalam berdakwah, da'i yang kental spiritual, pembaca yang kuat dan penulis produktif sekaligus piawai menyampaikan pandangannya secara ilmiah di mimbar-mimbar ceramah. Ketiga, relevansi setiap karyanya yang sesuai dengan perkembangan zaman. Karena landasan yang digunakan berdasarkan Al-Qu'ran dan Hadits shahih, menyentuh ke pokok persoalan sehingga karyanya dicetak beberapa kali oleh penerbit, termasuk di Indonesia. Keempat, ketokohan beliau dalam dunia pendidikan, dakwah, dan pergerakan diakui dunia sehingga beliau termasuk tokoh Islam yang berpengaruh abad 20 (Muhammad, 2006, p. 283). Atas pertimbangan-pertimbangan tersebut di atas penulis lebih ingin tahu dan tertarik meneliti terhadap konsep pendidikan akhlak menurut Sa'id Hawwa.

Sebelum diungkap lebih detail terkait pendidikan akhlak, maka perlu pula kiranya diuraikan terlebih dahulu pengertian pendidikan dan konsep akhlak. Pendidikan dari segi bahasa, kata "pendidikan" yang umum kita gunakan sekarang, dalam bahasa Arabnya adalah "tarbiyah", dengan kata kerja "rabba". Kata "pengajaran" dalam bahasa Arabnya adalah "ta'lim" dengan kata kerjanya "allama". Pendidikan dan pengajaran dalam bahasa Arabnya "tarbiyah wa ta'lim" (Daradjat, 2008, p. 3)

Ahmad Tafsir menambahkan, pengertian pendidikan; Pertama, pendidikan ialah pengembangan pribadi dalam semua aspeknya, dengan penjelasan bahwa yang dimaksud pengembangan pribadi ialah yang mencakup pendidikan oleh diri sendiri, pendidikan oleh lingkungan, dan pendidikan oleh orang lain (guru). Seluruh aspek mencakup jasmani, akal dan hati. Kedua, pendidikan adalah berbagai usaha yang dilakukan oleh seseorang (pendidik) terhadap seseorang (anak didik) agar tercapai perkembangan maksimal yang positif. Usaha itu banyak macamnya, satu diantaranya ialah dengan cara mengajarnya, yaitu mengembangkan pengetahuan dan keterampilannya. Selain itu, ditempuh juga usaha lain, yakni memberikan contoh (teladan) agar ditiru, memberikan pujian dan hadiah, mendidik dengan cara membiasakan dan lainlain yang tidak terbatas jumlahnya (Tafsir, 2008, p. 26).

Menurut Shalih bin Huwaidi Ali Husain dalam bukunya Mendidik Generasi ala Sahabat Nabi, sebagian diantara tujuan-tujuan pendidikan yakni: Pertama, menanamkan dan memperkuat iman; Kedua, mengembangkan dan 
menyebarkan akhlak baik; Ketiga, berpegang teguh pada kebenaran dan melawan kejahatan; Keempat, memperluas kaidah pemahaman pada anak didik; Kelima, kepribadian berilmu dan kehidupan berkembang yang terus beranjak naik guna mencapai kehidupan yang lebih leluasa (Husain, 2016, pp. 24-28). Sedangkan Ibnu Sina mengungkapkan bahwa, tujuan pendidikan adalah untuk mencapai kebahagiaan (sa'adat), kebahagiaan dicapai secara bertingkat, sesuai dengan tingkat pendidikan yang dikemukakannya, yaitu kebahagiaan pribadi, rumah tangga, masyarakat, manusia secara menyeluruh dan kebahagiaan akhir yaitu akhirat. Tujuan pendidikan harus diarahkan kepada pengembangan seluruh potensi yang dimiliki seseorang ke arah perkembangan yang sempurna, yaitu perkembangan fisik, intelektual dan budi pekerti. Lebih lanjut Ibnu Sina berpandangan bahwa tujuan pendidikan adalah untuk kemandirian dalam mengemban beban hidup dan memberi kemanfaatan kepada masyarakat dengan jalan membina tiap anggota masyarakat dengan pekerjaan mereka dengan baik.

Terdapat dua pendekatan yang dapat digunakan untuk mendefinisikan akhlak, yaitu pendekatan linguistik (etimologi, kebahasaan, lughat) dan pendekatan terminologik (peristilahan). Kata akhlak kalau kita terjemahkan secara bahasa berarti budi pekerti dan sopan santun. Kata akhlak berasal dari bahasa Arab, yaitu isim masdar (bentuk infinitif) dari kata akblaqa-yukhliquikhlaqan, sesuai dengan timbangan (wazan) tsulasi majid afala-yufilu-ifalan yang berarti al-sajiyah (perangai), al-thabi'ah (kelakuan, tabi'at, watak dasar), al-'adat (kebiasaan, kelaziman), al-maru'ah (peradaban yang baik), dan al-din (agama) (Mahmud, 2019, pp. 30-31).

Menurut Hadhiri pengertian akhlak menurut bahasa, akhlak berasal dari kata akblaqun, bentuk jamak, sedangkan bentuk tunggalnya adalah khuluq yang berarti perangai atau kelakuan, budi pekerti atau tabiat, kebiasaan atau tabiat. Sementara menurut istilah syar'i, beberapa pengertian akhlak pernah dikemukakan oleh para ahli, di antaranya: a) Akhlak adalah keadaan jiwa seseorang yang menimbulkan terjadinya perbuatan-perbuatan dengan mudah, b) Akhlak adalah sifat yang tertanam dalam jiwa yang timbul dari perbuatanperbuatan dengan mudah tanpa memerlukan pertimbangan fikiran sehingga keadaan itu menjadi kebiasaan, c) Akhlak merupakan ungkapan kondisi jiwa, yang begitu mudah bisa menghasilkan perbuatan tanpa membutuhkan pemikiran dan pertimbangan. Jika perbuatan itu baik, maka disebut akhlak baik, dan jika perbuatan itu buruk maka disebut akhlak buruk (Hadhiri, 2015, p. 14).

Tujuan akhlak menurut Jamhari dan Zainuddin yakni: Pertama, mendapatkan ridha Allah swt, sebagaimana dalam Q. S. Al-A'raf: 29; Kedua, membentuk kepribadian muslim, sebagaimana dalam Q. S. Fushilat: 33; 
Ketiga, mewujudkan perbuatan yang mulia dan terhindarnya perbuatan tercela (Zamhari \& Zainuddin, 1999, p. 76) .

Ibnu Miskawaih merumuskan tujuan pendidikan akhlak, dalam tahdib al-akhlaq, ialah terwujudnya pribadi susila, berwatak luhur, atau budi pekerti mulia. Dari budi (jiwa/watak) lahirlah secara spontan pekerti yang mulia sehingga mencapai kesempurnaan dan memperoleh sa'adat (kebahagiaan yang sempurna). Manusia tidak dapat mencapai kesempurnaan dengan hidup menyendiri, tetapi harus ditunjang oleh masyarakat. Pendidikan pada dasarnya menurut al-Ghazali adalah pendidikan akhlak, sehinggan ia merumuskan pendidikan untuk menghilangkan akhlak yang buruk dan menanamkan akhlak yang baik. Pertama, kesempurnaan manusia yang bertujuan mendekatkan diri kepada Allah swt. Kedua, kesempurnaan manusia yang bertujuan untuk mencapai kebahagiaan dunia dan akhirat.

Akhlak mulia merupakan tujuan pokok dalam pendidikan akhlak. Akhlak seseorang akan dianggap mulia jika perbuatannya mencerminkan nilainilai yang terkandung dalam Al-Qur'an. Untuk itu para Sahabat memiliki metode tersendiri dalam pendidikan dan pengajaran yang dapat disampaikan secara ringkas sebagai berikut.

Pertama, membina manusia dan menjaga kemuliaan serta sisi kemanusiaannya, sebagaimana dalam Q. S. Al-Isra': 70

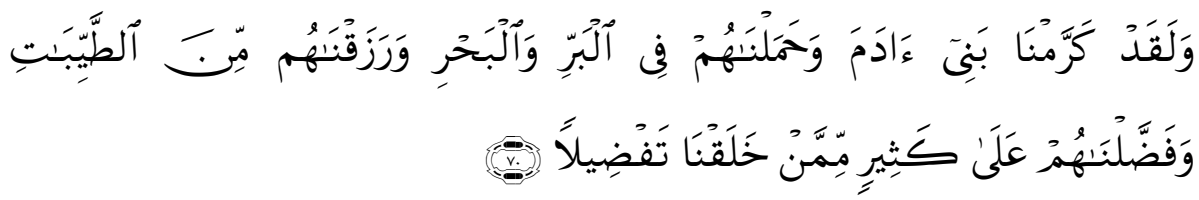

Dan Sesungguhnya telah Kami muliakan anak-anak Adam, Kami angkut mereka di daratan dan di lautan, Kami beri mereka rezki dari yang baik-baik dan Kami lebihkan mereka dengan kelebihan yang sempurna atas kebanyakan makhluk yang telah Kami ciptakan (Q. S. Al-Israa':70).

Kedua, metode pertengahan antara tegas dan lunak, Sebagaimana Q. S. Ali-Imran: 159. Metode pendidikan akhlak hendaknya mencontoh Rasulullah saw, untuk itu, pendidik harus memperhatikan maslahat murid, memperlakukannya layaknya memperlakukan anak yang paling ia sayangi, dengan mengasihi, menyayangi, memperlakukannya dengan baik, bersabar menghadapi sikap keras yang mungkin saja ia perlihatkan ataupun sikap kurang sopan yang sesekali dilakukan murid karena umumnya manusia tidak terlepas dari kekurangan seperti ini, sebisa mungkin menerima alasannya dan membimbing kesalahan yang ia lakukan dengan nasehat dan kelembutan.

Ketiga, bertumpu pada prinsip mencari maslahat dan menghindari mafsadat. Maksud dari metode ini dikarenakan setiap orang punya kebiasaan tersendiri, mungkin saja memperlakukan kebiasaan-kebiasaan ini secara 
terbalik akan menimbulkan keburukan dan fitnah yang lebih besar daripada maslahat mengamalkan sunnah. Dan mungkin saja tidak menjaga kebiasaan tersebut akan menimbulkan bahaya dan meninggakannya akan memicu kemungkaran.

Keempat, memperhatikan faktor usia, suku bangsa, dan lingkungan. Sebagaimana dalam Q. S. An-Nisa: 94. Untuk itu setiap da'i harus memulai dari tingkat pemahaman yang dicapai objek dakwah, bukan melalui tingkat pemahaman yang dicapai si da'i. Pendidik harus memperhatikan tingkat pemahaman dan kemampuan akal muridnya. Jangan menyampaikan sesuatu diluar jangkauan pemahaman dan akalnya. Dengan demikian, proses perbaikan dan pendidikan hanya bisa terlaksana dengan mengetahui karakteristik dan sifat-sifat para murid, memberikan penilaian, dan mengukur kekeliruan sesuai kemampuan yang dimiliki, karena menentukan hak dan kewajiban harus disesuaikan dengan tingkatan para da'i.

Kelima, berusaha untuk mengintegrasikan antara kebutuhan jasmani dan rohani. Untuk itu, salahsatu prinsip Rabbani dalam pendidikan adalah memadukan setiap ilmu dengan hal-hal yang dapat melunakkan hati demi terwujudnya ketenangan iman, agar hati tidak dikuasai akal saja sehingga makna-makna iman berubah menjadi filsafat mendalam dan tujuan-tujuan utama proses pendidikan lenyap begitu saja tanpa guna, karena tujuan mendasar dalam pendidikan adalah mengaitkan manusia dengan Rabb-nya, mengingatkannya pada akhirat, membuatnya bersemangat dalam menjalankan ibadah dan beramal (Husain, 2016).

Prinsip-prinsip dalam proses pembentukan akhlak, yakni: Prinsip pertama adalah nilai-nilai adab, kata adab dan akhlak sudah dipadukan dengan kata "Islami", maka arti keduanya hampir sama dan sulit untuk dibedakan, karena baik adab Islami maupun akhlak Islami berisi ajaran berperilaku yang baik menurut Islam atau menjauhi perilaku yang bertentangan dengan roh dan ajaran Islam (Hadhiri, 2015, p. 15). Ketika Imam Al-Junaidi ditanya tentang $a d a b$, ia menjawab," adab adalah baik dalam pergaulan dan interaksi. "Karenanya, urgensi adab tampak pada cara pergaulan dan interaksi, sehingga ia menjadi tampilan luar seseorang yang menunjukkan, apakah ia seorang anak-anak atau orang dewasa. Dan, adab menjadi prioritas utama dalam pendidikan akhlak bagi seorang anak (Suwaid, 2012, p. 263). Prinsip kedua adalah perilaku jujur, perilaku jujur merupakan bagian pokok dari prinsip akhlak Islami, yang membutuhkan keseriusan dalam menanamkannya dalam diri anak. Nabi Muhammad sendiri begitu besar memberikan perhatiannya pada perilaku ini. Beliau memperhatikan bagaimana pola interaksi orang tua dengan anaknya. Hal ini ditujukan untuk mencegah terjatuhnya orang tua pada perilaku dusta kepada anak. 
Prinsip ketiga adalah perilaku menjaga rahasia, dalam pertumbuhan anak, Rasulullah saw. memelihara mereka dengan perilaku menjaga rahasia, karena hal itu akan membawa kebaikan bagi seseorang untuk masa sekarang atau masa yang akan datang. Begitu juga akan membawa keselamatan dan kebaikan keluarga serta menjaga kebersihan masyarakat. Seorang anak yang terbiasa menjaga rahasia, akan tumbuh dengan memiliki kemauan yang kuat, tabah dan tegar. Terjaga ucapannya, sehingga tercipta budaya saling percaya dalam masyarakat, karena sebagian menjaga rahasia sebagian yang lain. Muslim yang ideal hendaklah menyimpan rahasia sesama muslim lainnya, sebagaimana dalam Q. S. An-Nisa: 83

Prinsip keempat adalah perilaku amanah, Amanah adalah perilaku dasar yang harus dimiliki setiap anak. Nabi saw. semenjak masa kanak-kanaknya hingga masa kenabian, disifati dengan sifat ini. Bahkan, orang kafir yang menentangnya memberikan gelar As-Shidiq Al-Amin (yang jujur dan dapat dipercaya). Ini bisa menjadi pelajaran bagi anak-anak muslim untuk selalu mencontoh perilaku Rasulullah saw, agar nantinya bisa membantu ketika ia berdakwah menyampaikan risalah Islam.

Prinsip kelima adalah perilaku kebersihan hati dari iri dan dengki, AtTirmidzi berkata bahwa ini adalah hadîts hasan gharîb dari Anas ra. bahwa Rasulullah berkata kepadanya.

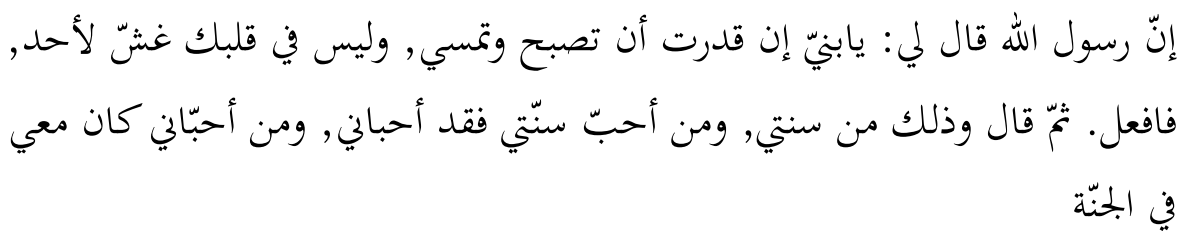

Wahai anakku, jika kamu mampu tiap pagi dan petang, dengan tidak ada iri dan dengki kepada siapapun dalam hatimu, lakukanlah. "Kemudian beliau berkata lagi, "Wahai anakku, itu adalah bagian dari sunnahku, dan barangsiapa menghidupkan sunnahku, maka sesungguhnya ia telah menghidupkanku. Dan barangsiapa menghidupkanku, ia akan bersamaku di surga.

\section{Metode}

Penelitian ini menggunakan pendekatan kualitatif, dengan metode studi pustaka (library research), adapun sumber data yang digunakan dalam penelitian ini yaitu buku-buku atau kitab-kitab karya Sa'id Hawwa yang berkaitan dengan pendidikan akhlak, kemudian dianalisis menggunakan teknik analisis isi (content analysis), sampai pada tahapan penarikan kesimpulan 


\section{Hasil san Pembahasan}

Konsep Pendidikan Akhlak Menurut Sa'id Hawwa adalah akhlak-akhlak Islam utama yang telah disebutkan karakternya oleh Allah swt. di dalam Al-Qur'an. Di mana kalimat hizbullah (pengikut agama Allah swt. ) disebutkan dua kali dalam Al-Qur'an, yaitu sekali dalam surat al-Ma'idah dan sekali lagi dalam surat al-Mujaadilah.

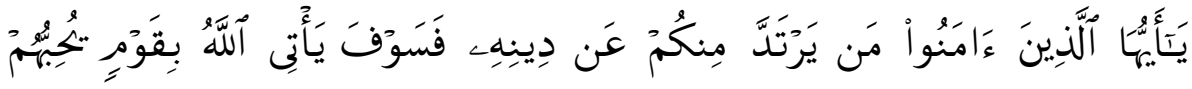

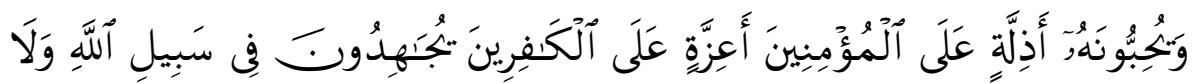

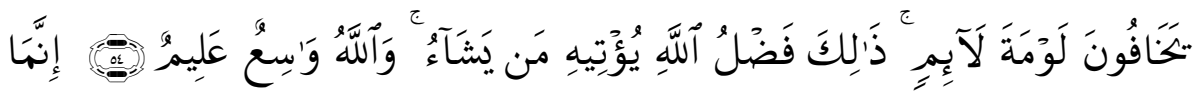

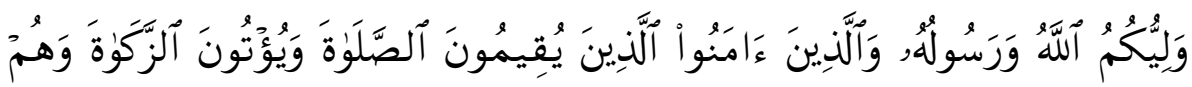

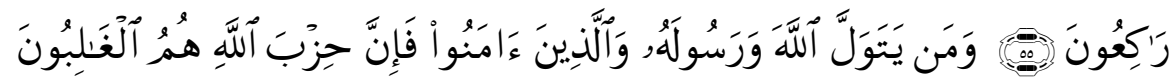

Hai orang-orang yang beriman, Barangsiapa di antara kamu yang murtad dari agamanya, Maka kelak Allah akan mendatangkan suatu kaum yang Allah mencintai mereka dan merekapun mencintaiNya, yang bersikap lemah lembut terhadap orang yang mukmin, yang bersikap keras terhadap orang-orang kafir, yang berjihad dijalan Allah, dan yang tidak takut kepada celaan orang yang suka mencela. Itulah karunia Allah, diberikan-Nya kepada siapa yang dikehendaki-Nya, dan Allah Maha Luas (pemberian-Nya), lagi Maha mengetahui. Sesungguhnya penolong kamu hanyalah Allah, Rasul-Nya, dan orang-orang yang beriman, yang mendirikan shalat dan menunaikan zakat, seraya mereka tunduk (kepada Allah). dan Barangsiapa mengambil Allah, Rasul-Nya dan orang-orang yang beriman menjadi penolongnya, Maka Sesungguhnya pengikut (agama) Allah, Itulah yang pasti menang. " (Q. S. Al-Maaidah: 54-56).

Jika diperhatikan, ayat tersebut menerangkan semua sifat hizbullah. Dengan dalil disebutkannya kata al-ghalabah 'kemenangan' pada akhir ayat. Disebutkan pula pada pertengahan ayat tesebut suatu kaum yang memerangi kemurtadan. Dengan demikian, kaum yang berhak meraih kemenangan adalah kaum yang memerangi kaum murtad dan mereka adalah hizbullah. Kemudian dalam surah al-Mujaadilah disebutkan kata hizbullah pada akhir ayat,

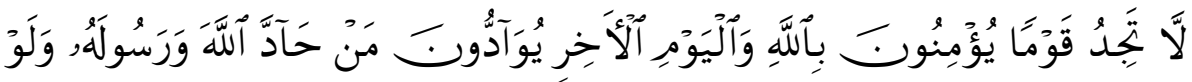

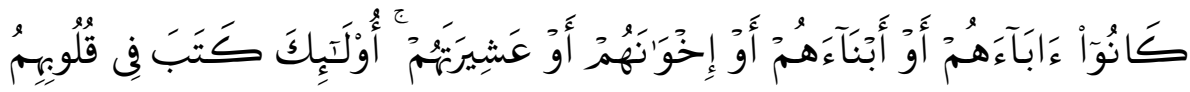

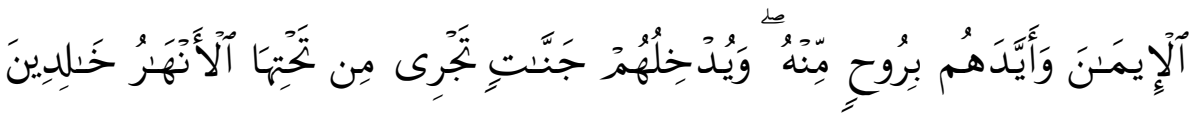




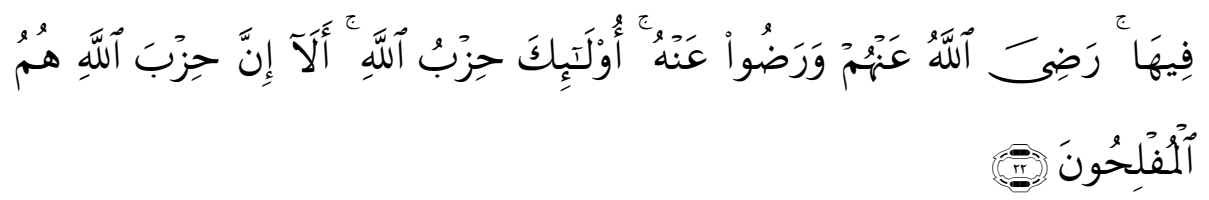

Kamu tak akan mendapati kaum yang beriman pada Allah dan hari akhirat, saling berkasih-sayang dengan orang-orang yang menentang Allah dan Rasul-Nya, Sekalipun orang-orang itu bapak-bapak, atau anak-anak atau saudara-saudara ataupun keluarga mereka. Mereka Itulah orang-orang yang telah menanamkan keimanan dalam hati mereka dan menguatkan mereka dengan pertolongan yang datang daripada-Nya. dan dimasukan-Nya mereka ke dalam surga yang mengalir di bawahnya sungai-sungai, mereka kekal di dalamnya. Allah ridha terhadap mereka, dan mereka pun merasa puas terhadap (limpahan rahmat)-Nya. mereka Itulah golongan Allah. ketahuilah, bahwa Sesungguhnya hizbullah itu adalah golongan yang beruntung." (Q. S al-Mujaadilah: 22)

Pertama, al-Wala', bermakna mengkhususkan loyalitas hanya kepada Allah swt, Rasulullah, dan orang mukmin. Manusia dalam kehidupan ini tidak ada yang dapat melepaskan dirinya dari hizbullah atau hizbusyaitan selain wala' ini. Jika wala' seseorang cacat, maka shalat, zakat, haji, dan puasanya, atau semua segi ibadah Islam tidak dapat membuat dirinya termasuk dalam hizbullah. Jika wala'-nya benar, dia berada dalam lingkungan hizbullah walaupun tidak dapat mencangkup seluruh ibadah.

Adapun bentuk aplikasi wala' kepada seorang mukmin adalah sebagai berikut. Pertama, Menolong orang-orang mukmin dan tidak merendahkannya. Kedua, Mengaitkan perjalanan hidup kita dengan kehidupan mereka. Ketiga, Tidak menaati orang kafir. Keempat, tidak segan memberikan rahasia-rahasia orang kafir dan langkah-langkah permusuhan mereka kepada kaum muslimin. Kelima, Mencintai muslim dan mendukung mereka di mana pun dan kapan pun mereka berada. Keenam, Bergaul dengan muslim. Demikian karakter paling asasi yang utama bagi individu muslim. Tanpa karakter tersebut, seseorang tidak akan menjadi muslim yang hakiki. Sebagai seorang muslim tidak boleh beramal melainkan karena Allah swt dan dilarang beramal, bekerja, dan membuat suatu pekerjaan kecuali apabila diperintahkan oleh Allah swt atau dibenarkan oleh Allah. Oleh karena itu, setiap amalan yang tidak disukai Allah swt ia akan menjadi maksiat, dan amalan yang diniatkan kepada selain Allah swt adalah syirik.

Seorang anak didik perlu dilatih dan difahamkan tentang pentingnya menuntut ilmu dalam rangka beribadah kepada Allah swt. Membiasakan berdoa khusu' sebelum dan sesudah melaksanakan kegiatan apapun, termasuk dalam belajar. Hormat dan patuh kepada guru, serta berkhidmat kepadanya dalam rangka mencari ridho Allah swt. Sikap lain yang dapat membatalkan shahadatain adalah riya', yaitu kegiatan hidupnya ingin pujian manusia. 
Perbuatan ini termasuk kategori syirik kecil, yaitu syirik yang dapat diobati dengan doa. Contohnya, mengerjakan shalat karena ingin dipuji dan diihat orang, bersedekah karena ingin dibicarakan dan disanjung orang, berjihad karena ingin dikenang dan menjadi terkenal, dan berkhutbah agar dianggap sebagai khatib (Hawwa, 2006: 163).

Kedua, al-Mahabbah, bermakna suatu ungkapan cinta seorang hamba kepada Allah swt. yang merupakan pengaruh alami yang timbul dari rasa syukur atas nikmat yang dikaruniakan Allah swt. kepadanya. Oleh karenanya, Rasulullah saw. bersabda, "Cintailah Allah swt. Karena ia telah mengaruniakan padamu segala nikmat-Nya dan cintailah aku karena Allah swt. Mencintaiku, dan cintailah Ahlul-Bait karena aku mencintai mereka. " (HR Tarmidzi). Dalam Al-Qur'an dan Sunnah Rasulullah saw. dijelaskan ada sekelomok manusia yang dicintai Allah swt. dan sekelompok manusia yang dibenci-Nya. Manusia hanya akan dibenci Allah swt. Jika ia melepaskan segala sifat yang dimurkai-Nya, lalu melaksanakan sifat-sifat yang dapat menimbulkan perasaan cinta pada Allah swt. pada dirinya. Terdapat tiga pembahasan mahabbah kepada Allah swt yang menggambarkan sekelompok manusia, yaitu: 1) orangorang yang dibenci Allah swt, sikap ini meliputi sikap-sikap yang menyimpang dari perintah Allah, baik dalam bentuk kekufuran, kemunafikan, kesesatan, maupun kefasikan yang semuanya termasuk dalam hal-hal yang diharamkan Allah swt (Hawwa, 2002, p. 211), 2) orang-orang yang dicintai Allah swt. Sikap ini meliputi sikap-sikap yang mengarah pada hal berbuat kebajikan (alihsan), suka bertobat setelah melakukan dosa, mencontoh Rosulullah saw sehingga menghantarkannya kepada ketakwaan. Adapun jalan meraihnya yaitu dengan bersikap cint karena Allah swt. , saling mengunjungi karena Allah swt. , memberi harta karena Allah swt. , bersaudara karena Allah, berperang di jalan Allah dan merapatkan barisan. 3) kecintaan manusia kepada Allah swt. Kecintaan kepada Allah swt menghendaki kita untuk mencintai orang yang dicintai Allah, dengan memperhatikan keutamaan orang-orang yang mempunyai keutamaan, dan iman tidak sempurna kecuali dengan ini. Allah swt. mencintai Rasulullah saw. dan Dia telah melebihkannya atas semua makhluk-Nya, sehingga mencintai kita kepada Rasulullah saw melebihi kecintaan kita kepada semua makhluk (Hawwa, 2003:403).

Pertama, bersikap lemah lembut terhadap orang-orang mukmin adalalah salah satu pengaruh kasih sayang terhadap mereka, dan bersikap keras terhadap orang-orang kafir adalah pengaruh dari syiddah 'sikap keras' terhadap mereka. Sebagaimana Allah menjadikan sikap lemah lembut dan rendah hati pada kedua orang tua sebagai pengaruh dari rahmat dan kasih sayang-Nya. Firman Allah dalam QS. Al-Maa’idah: 54) 


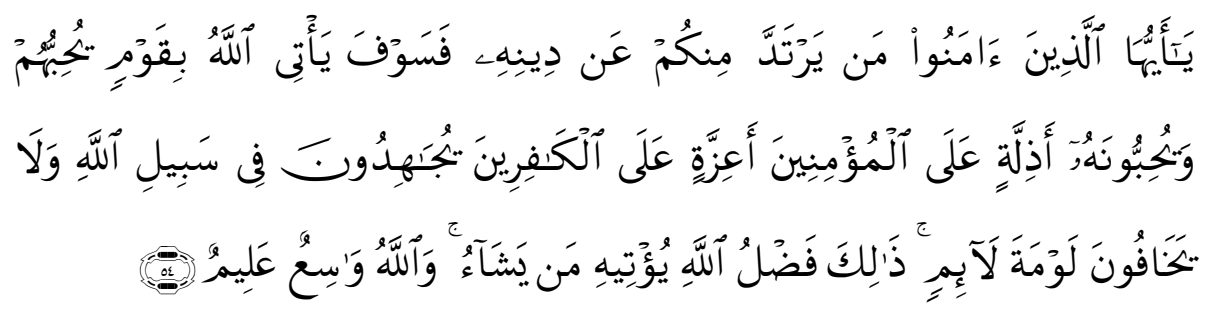

Wujud atau fenomena kasih sayang terhadap orang-orang mukmin dalam perintah AlQur'an dan ajaran-ajaran Rasulullah saw. Di antaranya; a) Memaafkan dan memohon ampun, serta bermusyawarah dengan mereka, b) Tawadhu (rendah hati) terhadap mereka, c) Menghilangkan hal-hal yang bisa menyakiti mereka. d) Berjumpa mereka dengan senyum berseri dan berbicara dengan perkataan yang baik. e) Meringankan kesulitan, kesusahan, dan menolong orang yang sangat membutuhkan pertolongan.

Kedua, Bersikap keras terhadap orang-orang kafir, Dunia dalam tatanan Islam, terbagi dua bagian: daerah atau kawasan perang (darul harb) dan daerah Islam (darul Islam). Sikap seorang mukmin terhadap orang-orang kafir dalam darul harb, dan sikap terhadap kaum kafir yang ada dalam darul Islam. Kedua sikap tersebut merupakan ungkapan dari kekerasan dan sikap tinggi hati terhadap kaum kafir. Dasar hubungan seorang muslim dengan orang-orang kafir dalam konteks ini adalah berperang sampai mereka mau masuk Islam, atau membayar jizyah dengan patuh dan tunduk, bukan perdamaian. Sebagaimana Allah swt. berfirman:"Hai orang-orang yang beriman, perangilah orang-orang kafir yang di sekitar kamu itu, dan hendaklah mereka menemui kekerasan daripadamu, dan ketahuilah, bahwasanya Allah bersama orang-orang yang bertaqwa." (QS. At-Taubah: 123)

Perdamaian yang dimaksud di sini adalah mereka harus tunduk dengan membayar jizyah, atau perdamaian sementara dengan ada perjanjian, jika kita tidak mampu mengalahkan mereka. Allah swt. berfirman, "Dan perangilah mereka, supaya jangan ada fitnah dan supaya agama itu semata-mata untuk Allah. " (QS. Al-Anfal: 39) Selain kondisi tersebut, hanyalah kondisi-kondisi darurat, baik berupa perjanjian, atau hidup damai. Hal tersebut dilakukan karena ada maslahat atau kepentingan, atau kita tidak terjerumus ke dalam multiperang, atau posisi muslim dalam kondisi lemah.

Menurut Sa'id Hawwa terdapat lima jenis jihad yang diisyaratkan dalam Al-Qur'an dan Sunnah yaitu jihad lisani, jihad taklimi, jihad tangan dan jiwa, jihad politik dan jihad harta.

Pertama, jihad lisani, beberapa catatan penting dalam proses jihad lisani: 1) yang tergolong dalam jihad dengan lidah adalah tabligh (mendakwahkan) Islam, dan menegakkan hujjah terhadap orang-orang kafir, munafik, dan fasik. Proses tablig atau penyampaian dakwah dan penegakkan hujjah ini adalah termasuk puncak Islam yang paling agung. Puncak Islam adalah jihad dan 
merupakan jihad paling agung. Target jihad dengan tangan tidak akan tercapai tanpa jihad lidah (Hawwa, 2002:424). Penyampaian dakwah dengan terang dan menyentuh hati adalah dengan hujjah yang jelas dan transparan. Hal ini tidak akan terjadi kecuali dengan pendidikan Islam yang tinggi. 2) memberi nasihat dan mengingatkan. Hal ini lebih pantas ditunjukan kepada orangorang mukmin. 3) mengumpat dan mencekam dengan kata-kata kasar dan keras. Hal itu dilakukan apabila tidak bisa mencegah dengan lemah lembut, dan terlihat adanya tanda-tanda kekerasan hati dan mencemooh wejangan dan nasihat. "Ah (celakalah) kamu dan apa yang kamu sembah selain Allah. Maksud mengumpat di atas bukan dengan melontarkan kata-kata kotor dan tidak pula kepada kebohongan, melainkan teguran yang tidak termasuk golongan kata-kata kotor. Tingkatan dalam jihad ini mempunyai dua etika: a) dai tidak boleh melakukannya kecuali bila darurat, dan bila tidak mampu lagi dengan lemah lembut. b) tidak mengucapkan selain kebenaran dan ketulusan dan jangan terlalu bertele-tele sehingga lidahnya (pembicaraannya) akan berpanjang lebar dengan hal-hal yang tidak diperlukan (Hawwa, 2002: 428).

Dengan demikian, jihad lisani berantai dalam bentuk formasi sebagai berikut. Tahap pertama penyampaian, penerangan, pelaksanaan, dan penjelasan hakikat-hakikat. Tahap kedua: pemberian nasihat, mengingatkan, dan membuat takut kepada Allah dengan cara lemah lembut dan kasih sayang. Tahap ketiga: jika dia seorang muslim kita harus mengerasinya: dan jika bukan seorang muslim: seperti seorang zimmi dan semacamnya, maka kita tetap berada pada batas-batas perdebatan dengan cara yang paling baik. Adapun media atau sarana jihad lisani dapat melalui majalah, surat kabar, ceramah, pengajian dan menerbitkan buku-buku islami.

Kedua, jihad taklimi (jihad pendidikan dan pengajaran) Al-Ghazali mengatakan 'wajib adanya di setiap masjid atau tempat dalam suatu Negara ada seorang yang faqih yang mengajarkan masyarakarat tentang agama mereka, demikian pula dalam setiap desa. Wajib atas setiap faqih setelah menyelesaikan fardhu ainnya, kemudian memfokuskan diri pada pelaksanaan fardhu kifayah, dengan keluar kepada orang-orang yang hidup bertetangga dengan wilayahnya: dari orang-orang hitam, orang-orang Arab, dan orang-orang Kurdi atau selain mereka. Mengajarkan agama mereka, dan fardhu-fardhu syariat mereka. Hendaknya ia membawa bekal makanan untuk dirinya, dan jangan makan dari makanan-makanan mereka karena sebagian besar adalah barang rampasan (Hawwa. 2002: 434).

Obyek jihad taklimi adalah mengusahakan orang yang telah menerima Islam untuk memberikan ilmu pengetahuan, pendidikan, dan pengajaran bagi mereka. Sedangkan jihad lisani adalah mengusahakan dengan lidah menentang penyelewengan, mengembalikan pelakunya kepada Islam atau memasukan 
mereka ke dalam Islam. Standar kesuksesn jihad ta'limi adalah kita mampu untuk memberikan kepada setiap muslim ilmu pengetahuan keIslaman secara komprehensif, dan pendidikan keIslaman yang benar, sehat, dan integral.

Ketiga, jihad dengan tangan dan jiwa, Jihad dengan tangan bermakna melawan orang-orang kafir atau mempertahankan diri karena diserang, melawan orang-orang murtad dan orang-orang zalim, orang-orang fasik, dan orang-orang ingkar. Karena syarat untuk lolos dari kehinaan yang ditimpakan kepada umat Islam sekarang ini adalah kembali kepada jihad, yang terdiri atas: 1) Berjihad dengan tangan di muka bumi Islam, dan 2) Berjihad dengan tangan di luar bumi Islam.

Keempat, jihad politik, politik Islam erat sekali dengan kekuasaan, pelayanan, dan perhatian yang serius terhadap rakyat. Jihad politik di jalan Allah swt disesuaikan dengan jenis pemerintahan yang ia alami. (Hawwa, 2003:451). Dalam konteks pemerintahan Islam yang adil kewajiban kita adalah tunduk dan patuh, setia, senantiasa memberikan nasihat, mendukung, dan memeliharanya. Rasulullah saw. bersabda, "Agama adalah nasihat! Kami mengatakan, 'Untuk siapa, wahai Rasulullah?'Beliau menjawab, 'untuk Allah, kitab-Nya, rasul-Nya, dan pemimpin-pemimpin muslim beserta umat Islam." (HR Muslim, Abu Dawud, dan Tamim ad-Daari)

Adapun dalam konteks pemerintahan yang kafir kita mempunyai lebih banyak kewajiban. "Hai Nabi, berjihadlah (melawan) orang-orang kafir dan orang-orang munafik itu, dan bersikap keraslah terhadap mereka. tempat mereka ialah Jahannam. dan itu adalah tempat kembali yang seburukburuknya." (At-Taubah: 73).

Kelima, jihad harta, Jihad ini merupakan syarat terhadap keempat jihad terdahulu dalam kinerja umum. Tidak akan bisa terlaksana satu jenis dari jenisjenis jihad kecuali dengan yang satu ini. Jihad ta'limi membutuhkan harta untuk pengadaan buku-buku dan pencurahan waktu serta tenaga para guru. Jihad lisani membutuhkan harta untuk buku-buku, koran-koran, dan majalahmajalah. Jihad dengan tangan membutuhkan harta untuk persenjataan dan perbekalan, serta infak untuk keluarga para syuhada. Jihad politik memerlukan harta untuk orang-orang yang memfokuskan diri dan para spesialis, dan untuk menciptakan sarana-sarana kekuatan.

Sumber utama konsep pendidikan akhlak yang dirumuskan Sa'id Hawwa adalah Al-Qur'an dan hadits. Hal ini terlihat jelas pada setiap penjelasanpenjelasannya yang selalu berlandaskan kedua sumber tersebut. Sehingga, masih terus relevan diterapkan pada setiap perkembangan zaman. Berikut ini akan coba diuraikan lebih dalam bentuk relevansi konsep pendidikan akhlak Sa'id Hawwa dengan pendidikan Islam saat ini. Sebut saja konsep pendidikan akhlak al-Wala' yaitu loyalitas atau kesetiaan sejati seorang mukmin hanya 
diperuntukkan kepada Allah swt, Rasulullah, dan orang mukmin. Bukan kepada organisasi, perusahaan, jabatan, harta maupun atasan. Oleh karena itu, al-wala' ini merupakan neraca bagi keimanan seseorang (Hawwa, 2002: 190). Kaitannya dengan dunia pendidikan, sebagai pendidik atau tenaga pengajar, sebaiknya mendidik atau mengajar niatkan dalam hati semata-mata mengharap ridha Allah swt, memiliki akidah yang kuat, menjadi teladan.

Konsep pendidikan akhlak yaitu al-mahabbah. Akhlak ini tumbuh dari pengaruh alami yang timbul dari rasa syukur seorang hamba atas nikmat yang dikaruniakan Allah swt. kepadanya. Cinta Allah swt. kepadahamba terjadi saat seorang hamba meniti jalan yang dibentangkan Allah swt. bagi kehidupan manusia dan menghindari yang tidak disyariatkannya (Hawwa. 2002: 210), idealnya seorang pendidik senantiasa menanamkan rasa cinta, mengajarkan syukur dan penuh kasih sayang. Kemudian diperkuat dengan pendidikan akhlak bersikap lemah lembut terhadap orang-orang mukmin, wujud akhlak ini berlaku pada semua orang mukmin karena adanya ikatan aqidah Islam. Bukan memberikan kasih sayang dan perendahan hati pada sebagian orangorang mukmin karena satu golongan, organisasi, satu syekh (guru) atau satu manhaj saja sedangkan bersikap keras terhadap selain mereka. Jika hal tersebut terjadi maka hal itu termasuk kekeliruan dalam mendidik (Hawwa. 2002: 412), pendidik selalu mendo'akan peserta didiknya, memaafkan, bersabar dan tidak menyakitinya.

Relevansi pendidikan akhlak bersikap keras terhadap orang-orang kafir, maknanya yaitu menanamkan rasa percaya diri yang tinggi kepada peserta didik, optimis, berperilaku baik memilih produk-produk muslim, dan pendidikan jihad di jalan Allah tanpa merasa gentar dari celaan orang. Amar ma'ruf, nahi mungkar, dan jihad adalah satu kesatuan dalam makna dan memiliki hubungan erat. Kedua istilah tersebut bisa digelarkan pada yang lain, di dalam wilayah Islam ataupun di luarnya.

\section{Kesimpulan}

Berdasarkan hasil penelitian diperoleh kesimpulan bahwa yang dimaksud Sa'id Hawwa dengan kewajiban membentuk kepribadian manusia secara Islami adalah setiap individu memiliki akhlak fundamental dan ilmu pengetahuan yang Islami. Kelima akhlak fundamental tersebut diantaranya adalah al-wala (loyalitas hanya kepada Allah swt, Rasulullah dan orang mukmin), almahabbah (cinta seorang hamba kepada Allah swt), adzilla 'alal-mu'miniin (bersikap lemah lembut terhadap orang-orang mukmin), 'izzah 'alal-kafirin (bersikap keras terhadap orang-orang kafir), al-jihad (berjihad di jalan Allah tanpa merasa gentar dari celaan orang). 
Kelima konsep pendidikan akhlak menurut Sa'id Hawwa tentu saja relevan dengan pendidikan Islam saat ini, dikarenakan sumber utama konsep pendidikan akhlak yang dirumuskan Sa'id Hawwa adalah Al-Qur'an dan hadits. Salahsatu contohnya adalah dari konsep al-wala' sebagai pendidik atau tenaga pengajar, sebaiknya mendidik atau mengajar niatkan dalam hati sematamata mengharap ridha Allah swt, Anak didik perlu dilatih dan difahamkan tentang pentingnya menuntut ilmu dalam rangka beribadah kepada Allah swt,; dari konsep al-mahabbah sebagai pendidik atau tenaga pengajar, senantiasa menanamkan rasa cinta kepada anak didiknya tanpa memilih dan memilah anak didik dari kepandaiannya, dari rupanya, dari kekayaan orang tua nya atau dari kedudukan orang tuanya; dari konsep bersikap lemah lembut terhadap orang mukmin, sebagai pendidik atau tenaga pengajar, dengan sesama pendidik di suatu lembaga saling berkasih sayang, tidak ada batasan antara atasan dengan bawahannya, senantiasa bersikap rendah hati, senantiasa mengajarkan kepada anak didik untuk bersikap lemah lembut dan saling tolong menolong; dari konsep bersikap keras terhadap orang kafir, menanamkan kepada anak didik untuk bertingkah dan berprilaku yang baik, tidak mencontoh sikap yang tidak baik dari orang non muslim; dari konsep aljihad, bersungguh-sungguh menguasai materi pelajaran dan memberikan keteladanan sikap dan tutur kata, mengusahakan perpustakaan di lingkungan sekolah dan masyarakat sebagai salah satu sumber ilmu dengan pengelolaan yang professional dan partisipatif, membangun atau mengembangkan majelismajelis keilmuan Islam.

\section{DAFTAR PUSTAKA}

Al-Banna, Hassan (2012). Kumpulan Risalah Dakwah Hasan Al Banna. Jakarta: Al-'I'tishom.

Daradjat, Zakiyyah. (2008). ILmu Penidikan Islam. Jakarta: Bumi Aksara. Hadhiri, Choiruddin (2015). Akhlak dan Adab Islam. Jakarta: Qibla.

Hawwa, Sa'id. (2002) Jundullah Mengenal Intelektualitas dan Akblak Tentara Allah. Jakarta: Gema Insani Press

Hawwa, Sa'id. (2006). Mensucikan Jiwa Intisari Ihya Ulumuddin. Jakarta: Robbani Press.

Husain, S. I. (2016). Asalib Tarbiyat an-Nasyi'ah Inda Ash-Shahabah. Jakarta: Griya Ilmu.

Mahmud, A. (2019). Ciri dan Keistimewaan Akhlak dalam Islam. Sulesana, Volume 13 Nomor 1, 30-31.

Muhammad, H. (2006). Tokoh-Tokoh Islam yang Berpengaruh Abad 20. Jakarta: Gema Insani Press. 
Suwaid, M. I. (2012). Cara Nabi Mendidik Anak. Jakarta: Al-I'tishom.

Tafsir, A. (2008). Ilmu Pendidikan dalam Perspektif Islam. Bandung: Remaja Rosdakarya Offset.

Ulwan, A. N. (1999). Pendidikan Anak dalam Islam. Jakarta: Pustaka Amani.

Zamhari, M. , \& Zainuddin. (1999). Al-Islam 2 (Muamalah dan Akblak). Bandung: CV Pustaka Setia. 